\title{
Improving the Professionalism of Cultural Arts Educators Through Online Base
}

\author{
Falihatul Ibriza Purnidya Anugrah*, Juju Masunah \\ Arts Education Study Program, Postgraduate School \\ Universitas Pendidikan Indonesia \\ Bandung, Indonesia \\ *ibrizafalihatul@gmail.com
}

\begin{abstract}
This paper aims to describe the professional development of arts and culture teachers in schools. It focuses on exploring: 1) the current professional condition of arts and culture teachers, and 2) the obstacles that arise in teaching practices. Employing qualitative descriptive method, this study gathered the information from arts and culture teachers through Musyawarah Guru Mata Pelajaran (MGMP) Seni Budaya, i.e. an official association for Arts and culture teachers, in DKI Jakarta, Indonesia. Questionnaire was used to explore attitudes and efforts of arts and culture teachers in Jakarta. This study concludes that the improvement of teacher professionalism can be done by using Online Base learning media. By using this media, the obstacles experienced by teachers in the teaching and learning process can be overcome. Students can use this onlinebased learning media to practice the skills taught by teachers in class. They can also repeat the lesson without being limited by space, time and place.
\end{abstract}

Keywords-arts educators, professional development, online base

\section{INTRODUCTION}

Cultural Arts learning is a part of the currently implemented curriculum, namely Curriculum 2013, with two hours time allocation per meeting. In addition to the cognitive or knowledge aspect, the subject also teaches skills and attitudes to the students. In its practice, skills learning take more time than the cognitive one. However, there are many teachers who found out that they are lacking of the time for skill practices. Meanwhile, the requirements of Kegiatan Belajar Mengajar $(\mathrm{KBM})$, i.e. teaching and learning activities, include the completion of the skill aspect.

The skills of the sub-fields of cultural arts (dance, music, visual art, and theater), regardless the obstacles, must be thoroughly mastered. This becomes the concern of cultural arts teachers in their respective field. Reflecting from the aforementioned issue, the author saw it as important to conduct a research which explores teachers' effort in overcoming any challenges in teaching cultural arts, particularly regarding dance as its sub-field. The study would show teachers' professionalism in performing their duties.
It is hoped that this study would provide solution in the world of education. The professionalism requires teachers to be able to keep up with the development in the era of Industry 4.0. Teachers need to recognize the existence of a virtual world that can overcome problems caused by distance, place, and time. Teaching and learning activities outside the classroom meetings which employ virtual communication might resolve the remaining problems of the allocated direct meetings.

The background issues emerge questions that will be addressed in this study. The questions are: (1) how do cultural arts teachers master learning through the Online Base? (2) What are the obstacles faced by Arts and culture teachers in their effort to improve the quality of learning through the Online Base? (3) How to overcome the obstacles that arise?

This research aims to: (1) describe how arts and culture teachers master learning through Online Base; (2) what are the constraints faced by Arts and culture teachers in an effort to improve the quality of learning through the Online Base; and (3) describe ways to overcome the obstacles that arise.

\section{LITERATURE REVIEW}

According to Ahmad D. Marimba the notion of teachers, as commonly used in society, gives the view that in general teachers are people who have the responsibility to teach [1].

Teachers are the human component in teaching and learning process that play a significant role in assisting students to the predetermined educational goals. Teacher professional competence becomes one of the competencies every teacher must possess at every educational level. The Law of the Republic of Indonesia No. 14/2005 concerning teachers and lecturers stipulates that "Teachers are professional educators whose main tasks are educating, teaching, guiding, directing, training, assessing, and evaluating students in early childhood formal education, primary education, and secondary education."

Teacher professional competences are a set of abilities that must be possessed by a teacher so that they can carry out teaching tasks successfully. The required competencies include pedagogical competence, personality competence, social 
competence, and professional competence. All of the competences are obtained through professional education. According to Tilaar, these professional competences include the ability to: develop the students' personality, especially their intellectual abilities, and make students be a good Indonesian citizen in accordance to Pancasila. Similarly, Nana Sudjana stated that one of the learning aspects that most dominantly affect learning outcomes is the teachers' teaching quality [2]. There are several other scholarly definitions of teacher professionalism, such as Ibrahim Bafadal who defines teacher professionalism as the ability of teachers to manage their selves in carrying out their daily tasks [3].

In summary, professional teachers are those who master the philosophy of national education, broad knowledge related to learning materials for students, and have the ability to compose learning programs and implement them. In addition, professional teachers are those who could perform assessments in the learning process, guide students to achieve the objectives of the learning program, and serve as administrators and communicators.

As written by Reza Aprilianto entitled Obstacles to the Implementation of Distance Learning (PJJ) during the Pandemic, along with the presence of the Covid-19 outbreak, provided new challenges for the world, both in terms of health, economy, and education, policies made by the Government for Pandemic This will indeed be detrimental to many parties, Lockdown and PSBB (Large-Scale Social Restrictions) policies in various parts of the world make the processes and systems of health and especially education have to be changed [4].

According to Pepen Permana, while discussing E-Learning and Online Learning, e-learning has the following characteristics [5]: (1.) Interactivity: the availability of various lines of communication, including synchronous (e.g. chat or messenger) and asynchronous (e.g. forums, mailing lists, or guest books). (2.) Independency: flexibility in the provision of time, place, teaching, and teaching materials. This makes learning to become more student-centered. (3.) Accessibility: the easier access for the distribution of learning resources by the employment of online tools in comparison to conventional learning. (4.) Enrichment: learning activities and presentation of the main and enrichment materials through the use of information technology tools such as video streaming, simulation, and animation. The four characteristics above are what distinguish e-learning from conventional learning activities.

\section{METHOD}

The study employed survey method, a research method in which the main data and information sources are obtained from respondents as the research sample by using a questionnaire as the instrument. Using Google Form, cultural arts or dance teachers filled out the questionnaire related to Pembelajaran Jarak Jauh (henceforth PJJ), i.e. remote learning. The questionnaire focuses on identifying the approach and the teaching method used by the teacher. It also explored Rencana Pelaksanaan Pembelajaran (henceforth RPP), i.e. teaching plan, adapted to the Covid-19 pandemic.

The participants in this study were Arts and culture (Dance) teachers in DKI Jakarta. They are members of the DKI Jakarta's Cultural Arts MGMP.

The data was obtained by distributing questionnaires online through Google Form. The study also used observation, interview, and documentation study. The teachers filled out the questionnaire according to the conditions they were experiencing. The questionnaire is particularly related to the way they develop remote learning during the Covid-19 pandemic, as well as the conveniences and challenges in teaching cultural arts or dance.

This study employed qualitative data analysis to explain the phenomena that occur in the research results. It was used to examine the professionalism improvement of cultural arts teachers through online base teaching media.

\section{RESEARCH RESULTS AND DISCUSSION}

From the research results, it can be taken as follows. The solution to increasing the professionalism of teachers in arts and culture is by (1) mastering the material, structure, concepts and scientific mindset that supports the subjects being taught. (2) mastering competency standards and basic competencies in the subject or field that is taught through an online basis $(73 \%)$. This means that the arts and culture teachers in DKI Jakarta province have mastered what is required in order to improve their professionalism as educators.

As for what $73 \%$ do, namely following web seminars (webinars) and similar activities organized by the government and private sector.

In addition, there are $27 \%$ of educators who develop their knowledge of cultural arts education reading scientific books about Cultural Arts education. Of the 27\%, efforts are made for them to continue to improve their knowledge of IT and put it in the form of use in learning media. Thus, these educators will become accustomed and develop along with the computerization era welcoming the industrial world 5.0.

Moreover, facing the COVID-19 outbreak in Indonesia in mid-March 2020 had a huge impact and changes in all aspects of life. One of them is changing the educational structure, starting from SD level to tertiary institutions. So, it is advisable to carry out teaching and learning activities at home (work from home) to minimize the transmission of the COVID-19 outbreak.

This is a challenge in itself, for art and culture educators and students to use IT.

The internet network is the only medium for teaching and learning activities.

One of the professional improvements made by cultural arts teachers in DKI Jakarta, is collaborating various remote tutor 
methods, various applications that are ready to use online (for example, google class rooms, schoology, zoom meetings, google meet, etc.) with teacher guidance. and parents. With the functioning of parents as tutors to replace teachers in schools to monitor children's learning development. The most important thing is the establishment of good communication between educators, students, and parents in distance learning.

As for the obstacles encountered by cultural arts educators in improving the quality of learning, $80 \%$ lies in the quota, namely the ability to provide non-technical infrastructure. The limited ability of students in operating cultural arts learning through an online base can be overcome by making tutorials in groups. They can learn independently so that they get knowledge from peer tutors. In addition, the internet network is an equally important obstacle in the implementation of cultural arts online. From the survey results, both educators, students and parents complained about the non-smoothness of the internet network which was the main obstacle in distance learning activities. In this case, of course, efforts are made to procure quotas so that learning can take place properly.

\section{CONCLUSION}

From the findings, it can be concluded that the majority of teachers chose to solve the encountered problem by utilizing external elements, such as using Google Form, Google
Classroom, Quizizz, WhatsApp Group, YouTube, Edmodo, Schoology, and so on. Those tools can be used to deliver materials online during the Covid-19 pandemic. In addition, teachers also approach parents and students so that all of those aforementioned programs would be understood and the implementation would be supported in the students' respective homes during the remote learning.

The convenience obtained by teachers through the employment of the online tools includes the capability to teach cultural arts (dance) without being limited by space, time, and place. Meanwhile, the challenges encountered in the remote learning implementation cover the limited equipment or infrastructure, less capable human resources (HR), and students' limited internet data.

\section{REFERENCES}

[1] D. Ahmad, Marimba. Pengantar Filsafat. Bandung: Al-Ma'arif, 1962, p. 37.

[2] N. Sudjana, Dasar-dasar Proses Belajar Mengajar. Bandung: PT. Remaja Rosdakarya, 2000, p 40.

[3] I. Bafadal, Peningkatan Profesionalisme Guru. Jakarta: PT. Bumi Aksara, 2000, p. 5

[4] M. Putra and R. Aprilianto, Kendala Pelaksanaan Pembelajaran Jarak Jauh (PJJ) dalam Masa Pandemi, 2020.

[5] P. Permana, E-Learning dan Pembelajaran Online. Padang: Ilmu Computer.Com, 2008, p. 8. 